\title{
Quiet Voices with a BIG Message
}

$\mathbf{W}$ hat if youthful wisdom brought into focus one of the prime absurdities of our humanity-that through our history, certain groups of people have dominated, persecuted, and made subservient other groups, simply using color, beliefs, or other reasons as justification? We don't have to look far to find these human inequities right within our own society, and right within young adult literature. There are a number of thought-provoking historical novels set in the not-too-distant past for middle and high school age readers with characters that appear to have quiet voices, but who speak up and act in a way that makes the world take notice about issues of discrimination. Their messages are worth hearing, and young adult readers can learn a great deal from these characters' quiet yet powerful challenges to situations that are inherently wrong.

The following books would make good choices for classroom reading, discussing, and studying about societal inequalities that have helped shape our history. Paired up with factual titles and informational articles, these middle readers and young adult novels can paint a portrait of unjust conditions more intently than a history text. They can help teen readers see parallels and contrasts in their own lives and in today's world. These books would also make excellent selections for teen book discussion groups and booktalks.

\section{Voices from the Tumultuous Sixties}

One well-known title that fits the above criteria is The Watsons Go to Birmingham, 1963 by Christopher Paul Curtis, which won a Newbery Honor. With humor and poignancy, Kenny, the young main character, relays how he and the rest of his African American family, the "Weird Watsons," head to Alabama to visit Grandma during the time of the civil rights movement. There they encounter the horrific 16th Street Baptist Church bombings that killed four young-teenage girls and seriously injured two more. Kenny's first-person voice clearly conveys the fear, anxiety, and turmoil of an innocent young boy who has faced such a challenging ordeal, and brings the heartbreaking injustices he has seen to life.

Another character who witnesses and expresses her feelings about related injustices is Celli Jenkins, in Black Angels by Rita Murphy. Celli is quite embarrassed by her greatly admired black housekeeper's involvement in the civil rights movement. Set in Georgia in 1961, the story is told in Celli's first-person voice. Through it, she shares the details of her mystical belief in beautiful black angels she sees around her home while relaying the stark reality of prejudice in her community, and ultimately unveils her own true heritage.

Flying South by Laura Malone Elliott (see the interview with Ms. Elliott following this article) deals with the same basic time period, and is told from the perspective of Alice, a pre-teen white girl who doesn't acknowledge or understand the existence of segregation in her town. Through her quiet and innocent voice, Alice teaches those around her a lesson or two they don't want or are not ready to hear. She even addresses another societal change that surfaced during that time period, when she says "But change is going to come whether they like it or not. The whole world is getting evened up. Even for girls.” 


\section{Voices as Forerunners of Change}

The civil rights movement in the United States, reflected in the above-mentioned stories, did not begin in a vacuum. It was the culmination of frustration and anger over years of injustice and inequality, and a demand to repair and compensate for innumerable wrongs. There are many quiet yet clear voices in young adult literature replicating the factual struggles that occurred in the decades before the tumultuous 1960s, leading up to that point. The following titles are good examples of other quiet voices that question injustices and hope for a better future.

Chris Crowe chronicles a dire situation and precursor to the civil rights movement that erupted in the mid-1950s, still echoed in the news today, in Mississippi Trial, 1955. The fictional voice of a 16year-old white Arizonan, Hiram Hillburn, who is visiting his grandfather in Mississippi for the summer, experiences the horror of racism when he is immersed in the true nightmare of the brutal murder of Emmett Till, an African American teenager from Chicago accused of whistling at a white woman. Hiram speaks up with information he knows about the suspected murderers, even though his grandfather warns him against it and it doesn't change the outcome of the trial. "It was the right thing to do," he says. Crowe's subsequent nonfiction companion, Getting Away with Murder, reinforces the fictional story.

Similarly, Devil at My Heels by Joyce McDonald zeros in on the Ku Klux Klan and its evil influences in the late 1950s. 15-year-old Dove Alderman is a white girl who lives a quiet life in the ironically named rural town of Benevolence, Florida. When she begins to see the growing injustices around her-mysterious fires being blamed on the black migrant workers on her father's farm, harassment of a young black friend and a white girl who fall in love, and suspicions of the KKK influence in her community-Dove has no choice but to speak out and stand up for what is right, even though it means a terrifying ordeal, and challenging and alienating her own father.

A reverse situation occurs in Lizzie Bright and the Buckminster Boy by Gary D. Schmidt, as the main character's father supports his son's decision to stand up for what is right rather than opposing him. Set decades earlier in a 1911 costal town in Maine, this powerful and brilliantly written Newbery and Printz honor book again brings fiction based on fact to life. In it, Turner Buckminster, the 14-year-old minister's son, who is white, befriends smart, perceptive Lizzie Bright, an African American neighbor his age from nearby Malaga Island. Although written in third person, Turner's voice comes through with humor, pathos, and clarity. When the townspeople decide to banish Lizzie and the members of her community so that they can take over and develop a tourist spot on her island, Turner speaks up against the cruelty and unfairness of the plan and tries to stop it. His father finally speaks up as well when he realizes Turner is right: "I will not stand with you at the destruction of Malaga Island. I will instead stand with my son."

A comparable story, set in the 1920's in a small Texas town, is Carolyn Meyer's White Lilacs, also based on an actual situation. Twelve-year-old artist Rose Lee Jefferson loves her home and family, and finds special pleasure in the beautiful gardens planted by her beloved grandfather. When she discovers the white townsfolk are planning to evict the African American Freedomtown community to the "sewer flats" so they can build a park in the center of town, Rose Lee realizes her voice of protest must be heard. Despite the sad outcome, Rose Lee's first-person narrative is powerful and moving.

Also set in the 1920s, Jonathan Scott Fuqua's Darby features a young white girl from Marlboro County, South Carolina, who writes an article promoting racial equality for the local newspaper. When the brave newspaper publisher agrees to print her innocent yet powerful viewpoint, the Ku Klux Klan is provoked. The publisher tells Darby, "You do realize that this is going to cause a certain amount of uproar?" And Darby responds, "Saying the truth is what newspaper girls do." Later, the publisher has a brick thrown through his window, and Darby's family finds a burning cross on their front lawn. Darby asks her mother if she is afraid. Her mother tells her no, that "in lighting that cross, they didn't push me down. They stood me up." Although Darby is only 9, the intensity of the story make it appropriate for middle grade and junior high readers.

A variety of voices speak of the fear instilled by the Ku Klux Klan in a1924 Vermont town, including that of a young African American girl and a young Jewish girl, in Karen Hesse's Witness. In verse novel form, which Hesse popularized through her Newbery 
winner Out of the Dust, she brings forth the startling and sad insight that the KKK was active in other places besides the southern United States at that time.

\section{Other Voices and Perspectives}

Two decades after Witness, on the opposite side of the world, 14-year-old Sorry Rinamu's fictional voice, in Theodore Taylor's The Bomb, focuses on the 1946 atomic testing by the United States on Bikini Atoll. Like Rose Lee in White Lilacs, he sees the injustice, inequity, and danger surrounding the plan to displace his people, and he sets off on a deadly mission to attempt recognition of and response to his voice of dissent.

Farther north in the Pacific, during World War II, Hawaiian eighth-grader Tomi Nakaji enjoys playing baseball with his friends and tries to live the life of a normal American teenager in Under the Blood-Red Sun, by Graham Salisbury. However, his Japanese heritage often triggers prejudicial behavior by others toward him. After witnessing the bombing of Pearl Harbor, Tomi sees his father and grandfather arrested simply because they are Japanese, and Tomi finds himself on a mission for justice, risking his own life for his family. Tomi also learns to stand up for himself, finally declaring to a man taunting him: "You got it wrong, mister. I was born here. I live here, just like you do. And I'm an American."

In the Newbery-winning Kira-Kira by Cynthia Kadohata, another American family of Japanese heritage moves from Iowa to Chesterfield, Georgia in the late 1950s. Sisters and best friends, Katie and Lynn Takeshima, realize quickly that people in their new town do not treat them as equals. Their parents get jobs in a poultry processing plant, where they work in deplorable conditions, have no time off for emergencies, but refuse to support the union in fear of being fired. When Lynn gets cancer, the family has no money to pay for the medical treatment she desperately needs, and Katie sees her sister's health fading away. After the ordeal with Lynn, their parents realize what matters in life, and finally stand up for what is right. Lynn had taught Katie the word "kira-kira," which means "glittering," and in her open and accepting way Katie herself learns what is important, when her quiet voice reflects: "My sister had taught me to look at the world that way, as a place that glitters, as a place where the calls of the crickets and the crows and the wind are everyday occurrences that also happen to be magic."

Chris Lynch's Gold Dust is set in Boston, where undercurrents of racial prejudice still fester in 1975. In the middle of the school year, Richard Riley Moncrief, who is white, befriends his new classmate, Napoleon Charlie Ellis, a dark-skinned boy from the island of Dominica. Napoleon is bright, interesting, and wears forthrightness like a shield against the bigotry around him. Even though Richard professes to be his friend, Richard is oblivious to Napoleon's sensitivity to the racially oriented comments and situations surrounding him. He also dreams of molding Napoleon into a huge baseball fan and dedicated player like he is. However, that's not Napoleon's dream. He would rather play cricket, be in a choir, and not have to deal with racial intolerance. It is the quiet voice of their friend Beverly who sees and wakes Richard up to the truth when she says, "Did you ever wonder, Richard, what Napoleon's dreams are? Did you ever even ask him?"

Another kind of intolerance comes to light when readers experience books about the plights and the controversies surrounding people coming across the southern border of the United States seeking a better life. A book that gives insights into their desperation, and that portrays realistically what life is like once they get here, is Journey of the Sparrows by Fran Leeper Buss. It was written with the assistance of Daisy Cubias, a native of El Salvador, and a poet, educator, and human rights activist. Journey of the Sparrows is beautifully told in the first person voice of sweet, heroic Maria, a 15-year-old Salvadoran who crosses the border in a crate, determined to earn enough money to help her family survive. Despite the harsh and cruel treatment she receives in Chicago, Maria manages to scrape by, and soon learns she must risk going back across the border to rescue her baby sister.

A pertinent concluding title, Crossing Jordan by Adrian Fogelin, takes a contemporary look at a close friendship between two girls in Tallahassee, Florida. Seventh-grader Cass Bodine, who is white, watches her father putting up a big fence one day during the summer, and learns it's because an African American family is moving in next door. He tells her "Good fences make good neighbors," and "If they stay out of our business and we stay out of theirs, we'll get along 


\section{An Interview with Laura Malone Elliott on Flying South}

Diane Tuccillo: What was your inspiration for writing Flying South?

Laura Malone Elliott: I had long had the character of a curmudgeonly but loveable gardener rattling around in my head. The character of Doc is actually based on a sketch I started in high school of an elderly man I knew and loved as a child. I always tell students to keep their journals and writing notebooks, because there will be the seeds of stories in them no matter how badly written they might have been originally! In journalism we call that "saving string."

But the concept of Flying South's story was born in sadness, when my father died. As I so often have as a parent when my children faced a difficult issue, I looked for a book to help my children deal with the loss of their grandfather. There are many gentle picture books and thought-provoking YA novels on the subject-but not as much for the middle reader. And so, I felt pushed to write one. My purpose was to reassure young readers that even though a loved person is gone, the influence and lessons shared remain as profound talismans.

As all pithy characters should be, Doc is an amalgamation of inspirations-people I have known, people I have read about, people I'd like to see on this earth. In Doc, there is definitely a bit of the old, rather crusty gentleman who was my friend; a dollop of some demanding and philosophic teachers I had; and a strong dash of my father who raised award-winning roses and so loved and celebrated the natural world.

There are many "messages" I hope Flying South shares-about friendship, the life force, the wonders and solace of nature, the gift of elderly wisdom, and the importance of a young person making his/her own decision about what is right and wrong, no matter what peers or society say. The civil rights movement provided the perfect test for the final theme.

All these concepts were inspiration that prodded me to write Flying South.
DT: For what reason did you choose to set the story in the late 1960s?

LME: Part of the reason rests in the fact I was about Alice's age during 1968 and when I've talked to my children about that time period, they often look at my blankly! One of the nicest reactions to Flying South is that mother-daughter book clubs choose to read it together. So, the 1968 setting was a way to expose children to that decade, to humanize the individual choices that have to be made during sweeping social change. A line from a critic I really appreciate: "Flying South shows how national movements, though they may seem distant today, were very real-and very personal-to the people who lived through them."

The late 1960s was such a pivotal time in American history in terms of attitudes and respect for the rights of others. Although laws were changed to demand equality and access to things as fundamental as a bus seat or public toilet, a subtler racism continued to permeate daily life. As Bridget - the voice of the status quo-says, " $\mathrm{Al}$ lowed and wanted are two different things." The only way for that difference to change is for people like Alice to have the courage and decency to speak up for it. Those smaller, day-to-day choices-which perhaps bring about a deeper, more permanent change-are not made on the Senate floor with inspiring oratory but at the lunch counter and the school playground facing down the intimidating disapproval of neighbors and classmates.

Setting Flying South in the late 1960s also allowed me to slip in some other social realities that are quite startling to young people today, especially to girls. That topic, of course, is discrimination based on sexism. While civil rights were finally becoming legal reality, women still had many battles ahead of them. The concept that women would be barred from state universities, or paid less for doing the same job as a man, or were frowned upon for having a career, or would tolerate-even expect-bullying by their spouse is quite shocking to our middle-grade readers. Thank 
goodness! But these are advances they should realize are relatively recent. These were topics I had written about as a journalist. Quite frankly, they slipped into Alice's narrative as themes without my really planning on it.

Finally, 1968 was a frightening, unpredictable year-assassinations, rioting, a bloody war that divided the country-not unlike the turmoil and uncertainty our children have faced since 9/11. I hope seeing Alice survive her challenges helps steel today's preteens to face their own with confidence and a commitment to doing what they know is right. As Doc says, "Life is going to test you. How you deal with those tests is the measure of what kind of a person you are."

DT: Alice is such a sweet and innocent, yet realistic and perceptive, character. Why did you choose the voice of such a preteen girl to demonstrate the folly of discrimination in our society?

LME: Those preteen years are so critical in terms of a young person learning to be true to himself, to hang on to an inner compass. The desire to belong and to fit in is so strong. Preteens are tested constantly in terms of having to choose between what they know is right and what those seemingly all-important social cliques want them to do. And so often, what cliques perpetuate is discrimination-ostracizing a child because he or she doesn't have popular clothes, music, or attitudes. Alice risks her "status" with Bridget, with her community, to stick to her love and respect for Edna, her mother, herself. And, of course, she falters at first under Bridget's influence. She hurts Edna. I hope Alice's faltering but ultimate success helps readers her age understand that each day offers a chance to begin anew and to break away from the pettiness and discrimination often perpetuated by "popular" kids.

DT: Doc says, "The more you challenge something, the more it produces . . . If you ignore them (the roses), they won't amount to nothing . . . sort of like children." Tell me about the symbolism of the roses, and why you included that element in the story?
LME: I have to admit that the symbolism of the roses was quite an organic and magical experience for me. They became a symbol as I wrote. The roses were there initially as backdrop because they are beautiful, I love them, and it seemed a natural thing for Doc to grow and cherish. My husband and I were married in my father's rose-garden.

I hadn't pre-planned the thorns and the blossoms to be a metaphor for the pain and the joy life brings us. And yet, as I wrote those paragraphs, it happened. I could hear my father's voice telling me that for a rosebush to thrive and continue to bloom, a gardener must prune away the dead to make way for new life. That roses needed careful and constant tending and were well worth the effort because what could be more breath-taking than a rose garden in full glory? And what could be a better analogy for the miracle and thrill of raising children? Or a better message for young peoplethat things worth doing require hard work and personal challenges?

I felt my fingers fly across the keyboard. I have to tell you that such spontaneous moments at the computer make a writer want to jump up and dance afterward!

That being said, I had very much planned on Doc's garden being a symbol of the life cycle, of rebirth, a clear reassurance of life going on, even after a loved person dies. I worry that so many of our children grow up as "hot-house" adults now, unused to witnessing a seed turning into a plant, stretching up toward the sun, blooming, "dying” during the winter, only to reappear the next spring. I think trusting in the earth's life continuum lends a perspective that builds resiliency and a deep appreciation of each moment we have here on earth. "Things have their time of beauty," as Doc says, and the trick is recognizing that and relishing it when it's happening.

I wear a bracelet with a prayer from the author Jane Austen inscribed on it: "Teach us that we may feel the importance of every day, of every hour, as it passes."

DT: The friendship between Alice and Doc, and the warm relationship between Alice and Edna, are exceptionally loving and beautiful. Why did you 
choose these intergenerational relationships to help fulfill the story's purpose?

LME: I was blessed to know a number of witty, wise, and vibrant elderly people as I grew up. In fact, someday I need to write a story inspired by my surrogate grandmother, who was a lawyer with the State Department back in the 1920s-talk about a ferocious and demanding intellect!

I made the relationship between Edna and Alice, Doc and Alice, as loving and strong as I did for a number of reasons. Mostly, it is a statement about friendship.

Young people need to know that friendstrue friends-can come in all colors, sizes, and ages. They don't have to be peers.

Older people bring such a wonderful perspective. As I grew up during Vietnam, the assassinations of the best and brightest of our nation, and the sordid details of Watergate, my hope in the prevailing good intentions of mankind was preserved by knowing people who had survived the Depression, deadly outbreaks of polio and influenza, World War II, the "Red Scare," and horrendous discrimination. They had a kind of matter-offact faith, knowing full well that change was brought about by courage and sacrifice but that man was completely capable of such bravery. They expected it of us, just as Doc and Edna expect it of Alice. By osmosis, their faith shored me up. Doc and Edna guide and lead Alice to what she knows in her heart to be right.

In our mobile culture, so many of our children grow up without consistent contact with older relatives. It's such a shame, especially because it puts so much pressure on the short visits they do have. Reaping the benefits of a relationship with older people requires a little patience-they move a little slower, want to tell metaphorical anecdotes that at first seem boring, or can be shorttempered because their joints ache. I hope readers will heed what Alice says about Doc: "You can't have your whole opinion about someone wrapped up in a bad moment. Give a person like Doc long enough and he might just say something wonderful."
Finally, living in a metropolitan area just outside Washington, DC, I witnessed a great many of my children's peers grow up with long-term nannies in their homes, replicating in many ways the relationship between Edna and Alice. Like Edna, many of these caregivers are devoted and loving, augmenting parental nurturing in ways extended family-members once did. Often, today's caregivers are recent immigrants, with limited English and different ethnic backgrounds. Sadly, I have seen some of these wonderful people treated with the same kind of disdainful haughtiness that Bridget displays toward Edna. I hope Bridget's snobbish, disrespectful conduct will prompt some soul-searching among more privileged children who might make similar mistakes. In that regardcivility and respect for all people no matter class or education-I still see parallels between 2005 and 1968.

DT: Alice is both innocent and wise. How does that combination make her a perfect channel for the BIG message?

LME: Remember that old saying: "Out of the mouth of babes ...?" Wisdom born of innocence is often the most clear-eyed because it is instinctive and uncorrupted. Alice has not yet been inculcated to what 1968 society held to be "correct." Preteens can be in that wonderful stage in life-smart and mature enough to consider more difficult questions, yet still relatively free of prescribed, traditional attitudes. Alice sees straight to the heart of things because she is not sophisticated enough to look at the trappings. When Bridget corrects her for inviting the African American mother and daughter into the all-white restaurant, saying "allowed and wanted are two different things," Alice doesn't understand the ugly, legal nuance of Bridget's argument. She misinterprets Bridget's statement, replying the mother and daughter did want to come in, she could tell. And that was the crux of the matter, wasn't it?

DT: It was. It was a very powerful and moving point in the book. 
LME: Doc tells Alice: "Stand up for yourself and what you know is right. Grown people come to believe a lot of foolish things because of money, status, old prejudices that their class of people tells them are proper. They're afraid of losing their place at the top of the hill."

I'll never forget my daughter's reaction to a book on the Underground Railroad when she was in first grade. She couldn't grasp what it was about. When I explained, she looked at me with complete horror and incredulity, "You mean, people owned people?"

DT: Near the end of the story, Grace (Alice's mother) stands up to Bill, saying, "It is time I follow her lead and stand up for myself and for her." How do you see this situation connecting to the bigger picture of the importance of civil rights in the story?

LME: I hope it shows that standing up for what is right is contagious! And that children can affect adults and lead by example. I think young people sometimes feel their actions, their voices, their beliefs will be ignored simply because they are children. They need to believe that taking a stand with conviction will inspire others to be brave as well.

DT: Have you heard from young people who have read your book? Have they expressed that they have gotten the BIG message from this quiet but powerful story?

LME: I haven't received as many letters about Flying South as I have for other YA novels, Under a Wartorn Sky and Annie, Between the States, which are both much more of an adventure story. Those two I hear about constantly. As you say, Flying South, is a quieter, more contemplative story. What I have heard and thrills me is readers actually quoting pieces of the text to me. One child told me that she tells her mother: "Give me a real hug not one of those quick for-show ones.” Another reader giggled over the line: "Bright red on a scowl is scary," a description of Grace's vibrant-colored lipstick.
Those are reactions to craft, of course, not comment on thematic content-but you can understand a writer's delight in them!

Still, I have been very gratified when asked to speak to schools on Flying South to hear students' insistent questions about why Bridget was the way she was, why were people so opposed to the African American mother and daughter entering the restaurant? They really get stuck on that, which is a terrific springboard for me to ask them why they think people believed race mattered. Then I can challenge them further, asking why they exclude their peers sometimes. All those disquieted "howcome" questions, as Alice calls them, tells me that they "get the big message" because it's as if they have an itch they can't quell. Also, one teacher laughed in telling me how she had cried as she read the ending to her classroom. Evidently, her emotional candor prompted a wide-ranging confession among her students to all the times they had behaved badly to people of other color or socioeconomic class.

I don't know that readers feel hit in the face with the "big message" of Alice's story. But I can see that her questions linger and prompt some soul searching. Sometimes it is the quiet but persistent thoughts that most affect us.

Early on in my writing career, my editor at the Washingtonian magazine gave me a simple but profound piece of advice: Remember that readers think. Allow them to digest and react to the meaning of scenes I painted or quotes I collected. In other words, show rather than tell, illustrate rather than preach. And look for inspiring stories rooted in everyday life, in adversity readers themselves might face so they can truly feel and understand it.

I've always tried to remember that, especially when writing for young people. They hate being lectured-a sure way to turn them off to any message you're trying to convey! My hope is that Flying South's themes are like a sweet, subtle tune that gets stuck in one's head and ends up being a permanent companion. 
fine." Cass doesn't agree with that, especially when she meets one of the new neighbors, a girl named Jemmie who is her age, also loves running, and is as determined as she is to read Jane Eyre. As their friendship grows, the girls' families try to keep them apart, and they worry what the other kids in school will think about their relationship, but the girls decide to stand together proudly and fight for their friendship as a team. When they do, there is no fence that can hold them back, and perceptive readers will understand that if more fences of bigotry were torn down, the world would be a better place.

\section{Many More Voices to Be Heard}

There are numerous quiet, but clear, voices in young adult literature that convey messages against racial, ethnic, and other forms of social intolerance. The titles represented here are just a selection of fine examples. To discuss a wider variety of YA books addressing the folly of humans treating one another with hatred, inequality, or unkindness, and the various kinds of discrimination that is the result, while featuring young adult characters who speak up for what is right, would take a whole book rather than an article! However, the titles represented here are a good start for exploring those important topics, and getting readers to think about and discuss an array of related, many-faceted issues.

\section{Bibliography}

Buss, Fran Leeper. Journey of the Sparrows. Dutton, 1991.

Curtis, Christopher Paul. The Watsons Go to Birmingham, 1963.

Delacorte, 1995.

Crowe, Chris. Mississippi Trial, 1955. Phyllis Fogelman, 2002.
---. Getting Away with Murder. Phyllis Fogelman, 2003.

Elliott, Laura Malone. Flying South. HarperCollins, 2003.

Fogelin, Adrian. Crossing Jordan. Peachtree, 2000.

Fuqua, Jonathan Scott. Darby. Candlewick, 2002.

Hesse, Karen. Out of the Dust. Scholastic, 1997.

-- Witness. Scholastic, 2001.

Kadohata, Cynthia. Kira-Kira. Atheneum, 2004.

Lynch, Chris. Gold Dust. HarperCollins, 2000.

McDonald, Joyce. Devil on My Heels. Delacorte, 2004.

Meyer, Caroline. White Lilacs. Gulliver, 1993.

Murphy, Rita. Black Angels. Delacorte, 2001.

Schmidt, Gary D. Lizzie Bright and the Buckminster Boy. Clarion, 2004.

Salisbury, Graham. Under the Blood-Red Sun. Delacorte, 1994.

Taylor, Theodore. The Bomb. Harcourt Brace, 1995.

Laura Malone Elliott is the author of the acclaimed World War II novel Under a War-torn Sky (Hyperion, 2001), for which she is currently researching and planning a sequel. Her other notable books are Annie, Between the States (Katherine Tegen, 2004), and Flying South. In 2006, her forthcoming book, a Revolutionary War story set in 1775, will be published. Ms. Elliott lives in Virginia with her husband and their two children.

Diane Tuccillo is the author of Library Teen Advisory Groups: A VOYA Guide, Scarecrow, 2005. She was the Young Adult Coordinator at the City of Mesa Library in Arizona for almost 25 years, frequently contributes book reviews and articles to the professional literature, presents workshops on teen library participation, and is an adjunct instructor at the University of Arizona teaching "Young Adults \& Libraries" and has taught the "Adolescent Literature" course at Arizona State University. Diane has presented at ALAN Workshops, is the Library Connection column editor for The ALAN Review, served on the ALAN Board of Directors, and is currently ALAN President. 
The ALAN Review Winter 2006 